Columbia Law School

Scholarship Archive

2006

\title{
Rational Choice and Developmental Influences on Recidivism Among Adolescent Felony Offenders
}

Jeffrey Fagan

Columbia Law School, jfagan@law.columbia.edu

Alex R. Piquero

apiquero@utdallas.edu

Follow this and additional works at: https://scholarship.law.columbia.edu/faculty_scholarship

Part of the Criminal Law Commons, and the Juvenile Law Commons

\section{Recommended Citation}

Jeffrey Fagan \& Alex R. Piquero, Rational Choice and Developmental Influences on Recidivism Among Adolescent Felony Offenders, 1st Annual Conference on EMPIRICAL Legal Studies PaPer; Columbia Public LAW RESEARCH PAPER No. 06-117 (2006).

Available at: https://scholarship.law.columbia.edu/faculty_scholarship/1417

This Working Paper is brought to you for free and open access by the Faculty Publications at Scholarship Archive. It has been accepted for inclusion in Faculty Scholarship by an authorized administrator of Scholarship Archive. For more information, please contact scholarshiparchive@law.columbia.edu. 


\title{
Columbia Law School
}

Public Law \& Legal Theory Working Paper Group

Paper Number 06-117

\section{RATIONAL CHOICE AND DEVELOPMENTAL INFLUENCES ON RECIDIVISM AMONG ADOLESCENT FELONY OFFENDERS}

\author{
BY: \\ PROFESSOR JEFFREY FAGAN \\ COLUMBIA LAW SCHOOL \\ - AND - \\ PROFESSOR AleX PIQUeRo \\ UNIVERSITY OF FLORIDA - FREDRIC G. LEVIN COLLEGE OF LAW
}

This paper can be downloaded without charge from the Social Science Research Network electronic library at:

$\underline{\text { http://ssrn.com/abstract }=914189}$ 


\title{
Rational Choice and Developmental Influences on
}

\section{Recidivism among Adolescent Felony Offenders}

\author{
Jeffrey Fagan \\ Law School and Mailman School of Public Health \\ Columbia University \\ $\&$ \\ Alex R. Piquero \\ Department of Criminology, Law and Society \\ University of Florida
}

June 2006

Please address all correspondence to:

Jeffrey Fagan

Columbia Law School

Columbia University

435 West $116^{\text {th }}$ Street

New York, NY 10027

Tel. 212.854.2624

Fax 212.854.7946

Email jfagan@law.columbia.edu 



\title{
Rational Choice and Developmental Influences on Recidivism among Adolescent Felony Offenders
}

\author{
Jeffrey Fagan* \\ Alex Piquero ${ }^{\dagger}$
}

\begin{abstract}
Recent law and scholarship has claimed that the developmental limitations of adolescents affect their capacity for control and decision making with respect to crime, diminishing their culpability and reducing their exposure to punishment. Social science has focused on two concurrent adolescent developmental influence: developmental the internalization of legal rules and norms that regulate social and antisocial behaviors, and the development of rational thought to frame behavioral choices and decisions. The interaction of these two developmental processes, and the identification of one domain of socialization and development as the primary source of motivation or restraint in adolescence, is the focus of this paper. Accordingly, we combine rational choice and legal socialization frameworks into an integrated, developmental model of recidivism. We test this framework in a sample of 1,385 adolescent felony offenders who have been interviewed at six month intervals for four years. Using hierarchical and growth curve models, we show that both legal socialization and rational choice factors influence patterns of criminal offending over time. When punishment risks and costs are salient, crime rates are lower over time. We show that procedural justice is a significant antecedent of legal socialization, but not rational choice. We also show that both mental health and developmental maturity moderate the effects of perceived crime risks and costs on criminal offending.
\end{abstract}

\section{INTRODUCTION}

Adolescence is a sustained period of psychological, social and biological development and change, and also a transitional period when risks of crime and other antisocial behaviors are greatest. Developmental change also leads to variable responses - both within and between individuals - to legal sanctions and

* Professor of Law and Public Health, Columbia University. This research was supported by generous grants from the John D. and Catherine T. MacArthur Foundation through the MacArthur Research Network on Adolescent Development and Juvenile Justice. Additional major funding was provided by the Office of Juvenile Justice and Delinquency Prevention, the National Institute on Drug Abuse, the National Institute of Justice, the State of Arizona and the Pennsylvania Commission on Crime and Delinquency. Our collaborators and Co-Investigators at the University of Pittsburgh, University of South Carolina, Temple University and Arizona State University have created this study and guided its development and execution. We are very grateful for the heroic efforts of the interviewers in Philadelphia and Phoenix whose efforts have produced the infrastructure for this research. All opinions are those of the authors.

${ }^{\dagger}$ Professor of Criminology, University of Florida. 
other social influences, as well as uneven capacities for internal regulation and control that are requisites for avoiding crime.

Recognizing the influence of development and change during adolescence, criminologists have focused recently on two concurrent developmental influences on the relationship between legal sanctions and criminal activity. One developmental process results in the internalization of legal rules and norms that regulate social and antisocial behaviors, and that create a set of obligations and social commitments that restrain motivations for law violation. This process of legal socialization has been studied intermittently over the past quarter century (see, for example, Easton, 1967; Tapp and Levine, 1977; Cohn and White, 1990; Fagan and Tyler, 2005), and rarely with population groups most heavily involved in violence or other criminal law violations. The effect of legal sanctions for law violations on the development of these norms among adolescents has never been studied.

A concurrent developmental process is based the emergence of rationality to frame behavioral choices and decisions. This construction of deterrence is closely attuned to experiences with both the social and personal costs and payoffs of offending, as well as punishment costs associated with legal sanctions. The interaction of these two developmental processes, and the identification of one domain of socialization and development as the primary source of motivation or restraint in adolescence, is the focus of this paper.

According to the deterrence doctrine, the imposition of punishment costs, to the extent that they are swift, certain, and severe should inhibit criminal activity (Beccaria, 18XX; Gibbs, 1975; Tittle, 1980; Zimring and Hawkins, 1973). The second source of influence comes from developmental theories which are broadly concerned with the development, over time and within persons, of personal development. Developmental theories suggest that a process of legal socialization, i.e., the process through which individuals acquire attitudes and beliefs about the law, influences the relationships of adolescents to the law, and influence the effects of legal sanctions on future criminal activity. These two theoretical domains, deterrence and legal socialization, interact to influence both the effects of sanctions and decisions to persist in or desist from criminal activity.

Although there has been much research on the role of deterrence and sanctions on future criminal activity (Nagin, 1998; Smith and Gartin, 1989) and somewhat less research on legal socialization (Tyler, 1990), this line of inquiry has concentrated more on adult, general population samples. Unfortunately, there exists no application of these sources of influence on the future criminal activity of serious adolescent offenders. This is an unfortunate happenstance since knowledge about the offending patterns in terms of persistence/desistance - and their correlates - of adolescent offenders is a significant policy concern (e.g., Laub and Sampson, 2001). In this paper, we use data from the Research on the Pathways to Desistance (RPD) project, a prospective study of 1,355 serious adolescent offenders from Philadelphia and Phoenix, to examine how deterrence and legal socialization relate to criminal activity over a two-year period. Before we present data on this issue, we provide brief overview of the literatures we seek 
to combine and integrate into a larger model of offender decision-making, legal socialization and deterrence.

\section{A. Legal Socialization}

Legal socialization is the internalization of law, rules, and agreements among members of society, and the legitimacy of authority to deal fairly with citizens who violate society's rules. What adolescents see and experience through interactions with police, courts and other legal actors shapes their perceptions of the relation between individuals and society. The effects of legal sanctions and punishments contribute to trajectories of legal socialization. For example, punishment can reinforce or weaken the development and internalization of legal and social norms. When sanctions are delivered fairly and proportionately, they reinforce the legitimacy of the law, and can contribute to compliance and desistance. However, when punishment is delivered unfairly and/or disproportionality, it leads to cynicism about the law, and can contribute to anger and persistence (e.g., Sherman, 1993).

Psychologists studying the development of moral values and orientations toward the legal system have emphasized the crucial role of the childhood socialization process on subsequent adolescent and adult behavior. For this reason, a great deal of attention has been focused by psychologists and other social scientists on the importance of developing and maintaining moral values in children (Hoffman, 2000; Mussen and Eisenberg-Berg, 1977), as well as on the childhood antecedents of a positive orientation toward political, legal, and social authorities (Easton, 1965; Parsons, 1967; Krislov et al, 1966; Melton, 1985; Tapp and Levine, 1977). This earlier focus on developing a positive social orientation has led to a number of studies of childhood socialization.

The findings of these studies provide evidence suggesting that the roots of social values lie in childhood experiences (Cohn and White, 1990; Easton and Dennis, 1969; Greenstein, 1965; Hyman, 1959; Merelman, 1986; Niemi, 1973; Torney, 1967). In particular, early orientations toward law and government were found to be affective in nature, and characterized by idealization and overly benevolent views about authority. These early views shaped the later views of adolescents, views that were both more cognitive and less idealized in form (Niemi, 1973). As a consequence, each stage of the socialization process is found to influence later, more complex, views.

The core argument underlying the legal socialization literature is that children develop an orientation toward law and legal authorities early in life, and that that orientation shapes both adolescent and adult law related behavior. Similarly, the psychological literature on the development of moral values suggests that values develop early in life, and similarly shape adolescent and adult behavior (Blasi, 1980). The studies within this literature support this argument by showing that both social orientations toward authority and moral values play a role in shaping the law related behavior of adolescents and of adults (Tyler, 1990). 


\section{B. Procedural Justice}

An important factor influencing the development of adults' views about legitimacy are their judgments about the fairness of the manner in which the police and the courts exercise their authority. Such procedural justice judgments are found to both shape reactions to personal experiences with legal authorities (Paternoster, Bachman, Brame, and Sherman, 1997; Tyler, 1990; Tyler and Huo, 2002; Piquero et al., 2004) and to be important in assessments based upon the general activities of the police (Sunshine and Tyler, 2003; Tyler, 1990). In both cases, adults view the police and courts as less legitimate when they personally experience or vicariously become aware of instances of procedural injustice. These same studies further indicate that adults usually define the fairness of procedures by considering four factors: the degree to which they have voice and can express their opinions and concerns; the neutrality and factuality of the decision-making procedures used; the politeness and respectfulness of their interpersonal treatment; and the degree to which they believe that the authorities are acting with benevolent and caring motives.

Accordingly, experiences with the law and legal actors will shape and modify trajectories of legal socialization. These subjective evaluations of fair and respectful treatment are not simply cold cognitions or judgments. Rather, these experiences carry with them an affective or emotional component that animates views about the legitimacy of the law, cynicism toward it, or a disengagement from the law's moral underpinnings. While fair treatment may enhance evaluations of the law, poor treatment may arouse negative reactions or even anger leading to defiance of the law's norms (Sherman, 1993; Paternoster et al., 1997; Piquero et al., 2004). This would suggest that procedural justice exerts both direct effects on compliance with the law as well as indirect effects by shaping evaluations of the law's legitimacy.

\section{Rational Choice}

In criminology, the deterrence/rational choice framework offers that behavior is determined, in part, by a weighing of the costs and benefits associated with criminal offending (Clarke and Cornish, 1985; Nagin, 1998). With regard to the costs of offending, classic depictions of the deterrence doctrine anticipates that swift, certain, and severe sanctions from formal systems of social control will deter future criminal activity (Gibbs, 1975; Tittle, 1980; Zimring and Hawkins, 1973). Additionally, formal sources of social control may spur more informal sanctions, from peers, families, and other social relationships that may ultimately lead to deterrence (Williams and Hawkins, 1986). These costs subsume several domains including social, legal, and personal costs of offending. With regard to the rewards of offending, individuals are influenced by both the social (status, material) and personal (affective, emotional) rewards that arise from involvement in criminal activity (e.g., Katz, 1988; Nagin and Paternoster, 1993). Examples of 
these rewards include the thrill or rush that arises from crime, as well as the increase in status that emerges from criminal involvement.

It is the case that much of the research dealing with deterrence/rational choice has been conducted with more normative samples, primarily high school (Paternoster, 1987) and college (Nagin and Paternoster, 1993; Piquero and Tibbetts, 1996; Pogarsky, 2002) students as well as more general population samples (Grasmick and Bursik, 1990). These studies tend to indicate that the certainty of sanction threats operates is a small, but significant deterrent to more minor forms of criminal activity (Nagin, 1998). Additionally, in most studies, individuals are sensitive to the rewards of criminal activity such that the perceived thrill/benefit associated with offending serves to increase the probability of crime above and beyond sanction threats (Nagin and Paternoster, 1993; Piquero and Tibbetts, 1996).

At the same time, several investigations have been conducted among adult offender samples, including incarcerated and active offenders (e.g., Apospori et al. 1992; Decker et al., 1993;Piquero and Rengert, 1999; Tunnell, 1992; Wright and Decker, 1994, 1997). Although some may suggest that the use of an offender-based sample can offer little to a complete understanding of criminal activity (i.e., by offending, these individuals have already shown that they are insensitive to sanction threats), evidence does suggest that sanction threats are still important considerations among offenders. For example, even among active offenders, interviewed in the community, deterrent considerations-especially in the certainty domain - operate as important determinants of criminal activity. Such offenders are sensitive to the likelihood of detection such that they are likely to select different (i.e., 'easier') targets based on the probability of detection as well as the probability of reward (see Decker et al., 1995; Piquero and Rengert, 1999).

But there also are several reasons why active offenders, whether adolescents or adults, may evidence lower sensitivity to sanction threats. First, their immaturity alone may attenuate their perceptions of risk and their evaluations of the consequences of criminal behavior. Second, they may discount, or deliberately devalue sanction threats which tend to be more future than present-oriented. For example, Nagin and Pogarsky have linked discounting to various deterrence concepts (Nagin and Pogarsky, 2001, 2003) as well as future-related problem behavior (Nagin and Pogarsky, 2004), while Pogarsky and Piquero (2003) found that the presence of the gambler's bias ${ }^{1}$ corresponded with lower sanction certainty estimates. Third, the spatial concentration of serious youth crime in disadvantaged neighborhoods may lower the perceived costs of punishment while inflating its social rewards of status and material gains (Fagan and Wilkinson, 1998a, 1998b; Anderson, 1999). High crime neighborhoods often have high unemployment rates, lower human capital, and lower wages, economic barriers that may influence how young offenders evaluate the returns from conforming behavior. Accordingly, if punishment is discounted by perceptions

\footnotetext{
${ }^{1}$ Under the gambler's fallacy, punished offenders reset their sanction risk estimate, apparently believing they would have to be exceedingly unlucky to be apprehended again (Pogarsky and Piquero, 2003)
} 
that compliance may not "pay," then incentives to avoid crime are compromised. Fourth, the contingent effect of sanction threats may be reduced by the high rates of punishment in these neighborhoods. Both the stigma costs are reduced as is its contingent probability, when would-be teenage offenders perceive sanctions as inevitable, widespread and not stochastically tied to criminal activity (Nagin, 1999; Fagan and Freeman, 1999).

Beyond rational discounting, the assumptions of rationality in most deterrence frameworks also are contradicted by the co-morbidity of mental health and drug dependence among active offenders (Kessler et al., 1994; Loeber et al., 1998; Huizinga and Jakob-Chien, 1999). Both conditions can potentially impair or skew rational calculations of risk and reward, and generate motivations that may skirt the caluculus of offending based on a narrower risk-reward model of decision-making. For example, Goldstein $(1985,1999)$ identifies motivations for aggression tied to both the psychoactive effects of drugs and involvement in drug violence (see, also, Fagan, 1990, 1994), while Link et al. $(1998,1999)$ show that irrationally perceived threats among the mentally ill can override their internal controls to produce aggression. Even when these impairments are absent, strong emotional arousal (via fear or anger) often trumps control and reasoning in violent interactions between teenagers and young adults in high crime settings (Fagan and Wilkinson, 1998a; Wilkinson and Fagan, 2000).

\section{Theoretical Integration}

In this paper, we combine the rational choice and legal socialization frameworks into an integrated, developmental model of recidivism. This integrated model may be found in Figure 1. The model assumes that individuals bring with them a stock of personal and vicarious experiences with regard to deterrence and legal socialization. Over time, these concepts operate to influence further criminal activity. We suspect that sanction threats and punishment costs will curtail crime while rewards and benefits will increase crime. Additionally, we suspect that legal cynicism will increase crime while legitimacy will reduce crime. Finally, we expect that 'good' experiences with the criminal justice system, specifically the police and the judge, will lead to reduced criminal activity.

We also predict that many of these concepts will interact with time to influence criminal activity in important ways. EXAMPLES Finally, because of the nature of our sample, and the documented mental health problems among correctional populations, we conduct additional, exploratory analyses where we examine the extent to which mental health impairments compromise both the influence of rational choice and legal socialization on recidivism.

\section{RESEARCH METHODS}




\section{A. Participants}

Participants in this study were 1,355 adolescents (1,171 males and 184 females) enrolled in the Pathways to Desistance study, a prospective study of serious juvenile offenders in two major metropolitan areas (see Mulvey et al., 2004). Study methods and procedures are described by Schubert, et al. (2004). Participants were adolescents 14-18 years of age adjudicated on a serious (i.e. felony) criminal offense in either juvenile or criminal court. Cases were randomly sampled in the juvenile court, with three exceptions. First, because drug law violations represent an especially large proportion of the offenses committed by this age group, the proportion of juvenile males with drug offenses was capped at $15 \%$ of the sample at each site. Second, to ensure adequate participation by females for statistical power, all females meeting the age and charge requirements were enrolled in the study. Similarly, all youths whose cases were being considered for trial in the adult system were eligible for enrollment. The sample includes approximately one in three adolescents adjudicated on the enumerated charges in these two locales during the recruitment period.

Social and legal characteristics of the sample are shown in Table 1. Participant were predominantly male $(86.4 \%)$, African American $(41.5 \%)$ or Latino $(33.5 \%)$, and between 15 and 17 years of age at recruitment. Most participants came from families that were socially and economically disadvantaged, with low human capital and limited family resources. Fewer than $6.3 \%$ had parents with a 4 -year college degree, and $33 \%$ had parents with less than a high-school education. Employment rates were low: while nearly two mothers in there $(63.7 \%)$ of the respondents' mothers were working, fewer than half the fathers $(48.2 \%)$ had fathers working outside the home (data not shown). Nearly four in ten come from single-parent households headed either by mothers $(33.6 \%)$ or fathers $(4.6 \%)$. Single mother households were headed by a biological mother who had either never been married $(18.4 \%)$, or was divorced, separated, or widowed (15.4\%); $13.6 \%$ of the participants lived with both their biological mother and father; $19.6 \%$ lived with a biological parent and step-parent; the remainder of the participants had other living arrangements (e.g., lived with other adult relatives), including $4.7 \%$ who lived with no adults in the home.

Most participants were recruited from the juvenile court (82.1\%). About half $(50.1 \%)$ were incarcerated in a prison or jail at the time of the initial interview. The average number of prior petitions in the past six months was 1.69; the total number of charges over their court history was 4.19 , including 0.43 drug charges.

\section{B. Procedures}

Eligible youths were identified from a daily review of court record information at each site. Adolescents and their parents (or a participant advocate in situations where parental or guardian contact was unobtainable) provided informed consent to participate in the study, with $20 \%$ of those approached (either the adolescent or the parent) declining to participate. Participants and their 
parents were informed about the federal confidentiality shields that prohibited our disclosure of any personally identifiable information to anyone outside the research staff. Participant were also told that we were legally obligated report any cases of suspected child abuse, or instances where an individual was believed to be in imminent danger either from a stranger or herself.

Baseline interviews were conducted within 75 days of adjudication for youths in the juvenile system. For youths in the adult system, baseline interviews were completed within 90 days their first appearance in the criminal court. In most cases, the baseline interview took place after the disposition (sentencing) hearing $(62 \%)$; in the majority of the remaining cases, the disposition hearing occurred before the six-month follow-up interview. Subsequent interviews were conducted at six month interviews over two years.

Interviews were completed at the participants' homes, institutional placement or in a secure but private location such as a library. Interview conditions emphasized privacy: interviews took place in settings that were out of hearing range. Trained interviewers read each item aloud and respondents generally answered aloud. However, in situations or in sections of the interview where privacy was a concern, a portable keypad was provided as an option to obtain a nonverbal response. Interviews after the baseline took about two hours to complete. Participants were paid $\$ 75$ for their participation. The initial interview was completed in two two-hour sessions, and subsequent interviews each took two hours.

Retention across waves has been very high: about $93 \%$ of the scheduled interviews at each time point were completed on time. As a result, after 24 months, $84 \%$ of the participants did not miss any interviews (they have a baseline and four time point interviews) and $93 \%$ have three or four of the time point interviews. Overall, $2 \%$ of participants dropped out of the study and $2 \%$ died during the follow-up period.

\section{Measures}

Measures were developed in several domains: self-reported and official offending, costs and rewards of offending, legal socialization, procedural justice. In addition, we included measures of psychosocial maturity, substance abuse and mental health to control for individual differences among participants. Measures were collected at each wave. Scale means and standard deviations are reported in Table 2, and their psychometric properties are shown in Table 3. Scale properties were computed from confirmatory factor analyses and reliability analyses. Results show that measures for both the theoretical variables and the covariates are reliable and strong.

\section{Self-Reported Offending and Criminal History}

Delinquent Activity. A 24-item Self-reported Offending Scale was adapted from Huizinga, Esbensen, \& Weihar (1991) to measure involvement in antisocial and illegal activities. The 24-item additive scale included items about 
any participation in each type of delinquent behavior over the past six months. Variety scores were computed as a rate of the total number of items endorsed (see, Thornberry and Krohn, 2000). We computed offending variety scores to measure each of three different types of behaviors in the past year: total offending (24 items, $\alpha=$.884), aggressive offending (11 items, sample item "Have you ever beaten up, threatened, or physically attacked someone as part of a gang?", $\alpha$ $=. .744$ ), and income offending (11 items, sample item "Have you ever taken something from another person by force, without a weapon?", $\alpha=.798)$.

Court History. From court records, we computed the number of prior court cases, the number of prior charges, and the number of prior drug charges for each participant.

\section{Costs and Rewards of Offending}

Social and Personal Rewards and Costs of Offending. Measures for personal and social costs and rewards were adapted for this study to measure the adolescent's perceived likelihood of detection and punishment for any of several types of offenses (Nagin and Paternoster, 1994), the social and personal costs of punishment (Williams and Hawkins, 1986; Grasmick and Bursik, 1990), and the social and personal rewards of offending (Fagan and Wilkinson, 1998b; Anderson, 1999). Separate scales were developed along five dimensions: Certainty of Punishment [Others \& You (e.g., "How likely is it that kids in your neighborhood would be caught and arrested for fighting?")], Social Costs of Punishment (e.g., "If the police catch me doing something that breaks the law, how likely is it that I would be suspended from school?"), Social Rewards of Crime [Stealing, Fighting \& Robbery (e.g., "If I take things, other people my age will respect me more.")], and Personal Rewards of Crime (e.g., "How much 'thrill' or 'rush' is it to break into a store or home?").

Punishment Costs. For this project, we developed original scales to measure the extent to which the deprivation of liberty associated with correctional punishment is a personal burden that weighs cognitively and emotionally on young offenders, and that in turn might influence their decisions to engage in crime once they obtain their freedom. Separate scales were developed for deprivation of everyday freedoms (e.g...,"Has your court sentence kept you from hanging out with your friends as much as you used to?"), and material costs (e.g., "Has your court sentence kept you from buying things that you want, like music or videos?" Has your court sentence stopped you from being in a warm or comfortable place?"). An additive scale was computed based on the total number of items endorsed.

\section{Procedural Justice}

Procedural justice represents perceived quality of interactions with legal actors including police, school security officers, and store security staff. We adopted measures used by Lind, MacCoun et al. (1989, cited in Tyler and Lind, 1992), and Paternoster et al. (1997) to assess procedural justice. The subscales 
are based on their recent encounters with legal actors (e.g., ethicality, fairness, representation, consistency, respect, correctability) (e.g., "During your last contact with the police when you were accused of a crime, how much of your story did the police let you tell?"; "Think back to the last time you were before a judge because of something you were accused of doing. Did the judge treat you with respect and dignity or did he/she disrespect you?"). These measures have proven to be robust predictors of legal compliance under a wide range of sampling and measurement conditions including general population surveys, criminal justice defendants, mediation and arbitration participants, persons filing workplace grievances, and participants in tort litigation (Tyler and Lind, 1992: 124-37). These measures have only recently been extended to persons in the criminal justice system (Paternoster et al., 1997) and to adolescents (Fagan and Tyler, 2006).

We disaggregated interactions between police and courts, and developed separate measures for both the respondents' experiences and his or her assessments of how similarly situated youths are treated by the police and the courts.

\section{Legal Socialization}

Legal Cynicism. Following Sampson and Bartusch (1998), we modified Srole's (1956) legal anomie scale to create a measure of Legal Cynicism that assesses general values about the normative basis of law and social norms. The items assess whether laws or rules are not considered binding in the existential, present lives of respondents (Sampson and Bartusch, 1998). Respondents are asked to report their level of agreement with five statements, such as "laws are made to be broken" and "there are no right or wrong ways to make money." The measure is computed as the mean of the five items. Reliability across waves was high (alpha $=.061)$.

Legitimacy. We adapted Tyler's $(1990,1997)$ measure of legitimacy of law and legal actors. Items measured respondent's perception of fairness and equity of legal actors in their contacts with citizens, including both police contacts and court processing (Tyler and Lind, 1992; Tyler, 1997; Tyler and Huo, 2002). The scales measure the experiential basis for translating interactions with legal processes into perceptions and evaluations of the law and the legal actors that enforce it. Respondents indicate their agreement with 11 statements such as "overall, the police are honest," and "the basic rights of citizens are protected by the courts." The measure is computed as the mean for the 11 items; reliability across waves was high (alpha $=.080)$.

\section{Mental Health, Maturity, and Substance Dependency}

We included covariates in three domains to incorporate factors that are potential modifiers of both rational choice and developmental influences on criminal behavior: measuring mental health, substance abuse, and psychosocial maturity. 
Mental Health. We use the Brief Symptom Inventory (BSI) Global Symptom Index to measure current general psychopathology and psychological distress (Derogatis \& Melisara, 1983). The BSI is a 53-item self-report inventory in which participants rate the extent to which they have been bothered ("not at all" to "extremely") in the past week by various symptoms(e.g., "Having to check and double-check what you do"; "Faintness or dizziness" "Feeling inferior to others"; "Feeling tense or keyed up"). We use the global psychological distress subscale (GSI). Reliability for the Global Severity Index (GSI) is reported as .95 (Derogatis \& Melisara, 1983).

Psychosocial Maturity. The Psychosocial Maturity Inventory (PSMI Form D; Greenberger, Josselson, Knerr, \& Knerr, 1974) has been used in previous research and shown excellent validity and psychometric properties (Greenberger $\&$ Bond, 1976). The scale contains 30 items to which participants respond on a 4point Likert scale ranging from "Strongly Agree" to "Strongly Disagree". We use the summary score for the 30 items $(\alpha=890)$, which includes items from three domains: personal responsibility or self-reliance (i.e., feelings of internal control and the ability to make decisions without extreme reliance on others, e.g., "Luck decides most things that happen to me" [reverse coded]), identity (i.e., selfesteem, clarity of the self, and consideration of life goals, e.g., "I change the way I feel and act so often that I sometimes wonder who the 'real' me is" [reverse coded]), and work orientation (i.e., pride in the successful completion of tasks, e.g., "I hate to admit it, but I give up on my work when things go wrong" [reverse coded]).

Substance Abuse. We use the Substance Abuse Dependency Scale, part of the Substance Use/Abuse Inventory developed by Chassin et al. (1991) in a study of children of alcoholics. This measure considers the adolescent's use of illegal drugs and alcohol over the course of his/her lifetime and in the past six-months. We use the items measuring dependence in the most recent six months preceding each interview $(\alpha=\mathrm{XXX})$. The self-report measure for dependency includes selfreport items that describe symptoms including conflicts when intoxicated, failed efforts to stop, physical symptoms of withdrawal, and compulsion to get high or drunk (e.g., "Have you ever had problems or arguments with family or friends before because of your alcohol or drug use?"; "Have you ever wanted a drink or drugs so badly that you could not think of about anything else?"; "...[H]ave there been times when you stopped, cut down, or went without drinking/using drugs and then experienced symptoms like fatigue, headaches, diarrhea, the shakes, or emotional problems?"; "Have you tried to cut down on alcohol/drugs but found that you couldn't?").

\section{Analysis}

We developed individual growth curve models to estimate the effects of the theoretical variables on patterns of self-reported offending over two years following the baseline assessment. Models were estimated using linear mixed models that contain both fixed and random effects (Singer, 1998; Singer and 
Willett, 2004; McCullogh and Searle, 2001; Raudenbush and Bryk, 2002). To control for site differences, we nested subjects within sites and also controlled for sites.

We estimated models in two stages. First, to identify the relationships between legal socialization, rational choice and procedural justice measures, we estimated models predicting separately legitimacy and legal cynicism. Predictors included rational choice (costs and rewards of offending) and procedural justice variables, and a set of control variables for individual differences (maturity, mental health, and substance dependency) plus demographics and site. We use random intercepts to account for variations in starting points. We included both linear and quadratic terms for time (wave) to reflect the negative exponential distribution of the dependent variables over the five time points. Predicted values for each measure were then computed.

Next, we estimated models predicting three dimensions of self-reported offending from legal socialization (predicted values), rational choice (costs and rewards) and procedural justice. We included fixed effects both for the theoretical predictors (costs, rewards, legal socialization, procedural justice) and the same control variables. We again used random intercepts to account for variations in starting points. We again included both linear and quadratic terms for time (wave) to reflect the negative exponential distribution of the dependent variables over the five time points.

In all models, we treat time as both a random and fixed effect, to explain specific time effects as well as change over time. We use an autoregressive covariance structure to reflect the within-subject correlation in self-reported offending over time. We use REML methods to develop linear contrasts of the response variable that do not depend on the fixed effects but depend instead on the variance components to be estimated. Following Singer and Willett (2004), we include interactions of the quadratic time measure with each of the theoretical predictors to determine the contributions of each predictor to the model.

The general model form for the offending models is:

$$
\text { (1) } \begin{aligned}
Y_{i j}= & {\left[\gamma_{00}+\gamma_{10} \operatorname{TIME2}_{i j}+\gamma_{01} L S_{i}+\gamma_{11}\left(L S_{i} \times T I M E 2_{i j}\right)\right] } \\
& +\left[\zeta_{0 i}+\zeta_{1 i} T I M E 2_{i j}+\varepsilon_{i j}\right]
\end{aligned}
$$

where LS represents each of the theoretical predictors, including legal socialization, procedural justice, and costs and rewards of offending. The crosslevel interaction, LS*TIME2 identifies whether the effects of TIME differ by the levels of the theoretical predictors (LS). The model is specified with both linear and negative exponential terms for time. We estimated models with time-varying covariates for each of the theoretical measures and for the covariates, where both slopes and intercepts vary; residual observations within subjects are correlated through the within-tract error-covariance matrix.

\section{RESULTS}




\section{A. Legal Socialization}

In the integrated theory, we specify each dimension of legal socialization as the product of the interactions of individuals with law. That is, we hypothesized that perceptions of procedural justice in respondents' direct and vicarious experiences with legal actors would influence the evaluation of the legal institutions those authorities represent, and the internalization of their underlying norms and law. We also assume that characteristics of the sanctioning context also influence legal socialization. Since law and legal actors also influence the sanctioning environment, we hypothesized that perceived sanction risks and rewards would reflect the internalization of legal norms as expressed by legal actors. To examine these relationships, we began with models to assess the contributions of rational choice and procedural justice influences on two dimensions legal socialization over time.

\section{Insert Figures 2 and 3}

Figures 2 and 3 show the changes in each dimension of legal socialization over time. Changes are small and the patterns differ. Legitimacy declines slightly from the first to the second wave, but then increases steadily from waves 2 through 4 . The pattern of change in legal cynicism is inconsistent over time, and changes from one wave to the next, whether increasing or declining, are small. The differences over time in the trajectories of each dimension of legal socialization suggests that they be estimated as separate constructs, and included separately in the second stage models of offending.

\section{Insert Table 4}

Table 4 shows the results of the legal socialization models. Following Singer and Willett (2004), we focus on the interactions of each predictor with time (exponentiated) to identify significant predictors. For legitimacy, the first column of Table 4 shows that both rational choice and procedural justice components influence legitimacy over time. But the effects are in the opposite direction of the predictions. Punishment risk is a significant but negative influence on legitimacy: when punishment risks are higher, perceived legitimacy is lower over time. Similarly, social costs, or stigma costs, also are significant but negative predictors over time. Both dimensions of procedural justice are significant and positive predictors of legitimacy, as expected. So too is one of the dimensions of punishment costs. The contrasting influences of law show the importance of disaggregating evaluations of outcome- versus process-based dimensions of legal interactions.

The second column of Table 4 shows that neither rational choice nor procedural justice factors influence legal cynicism over time. The upper half of the column shows that some components of risk, reward and procedural justice explain differences averaged across waves, there are no few influences among the theoretical predictors that explain change over time. One reason might be that 
there is so little change to explain: Figure 3 shows little overall change over time, despite the incremental small increases and declines from one wave to the next.

\section{B. Self-Reported Offending}

Figure 1 shows that rational choice and procedural justice factors are direct influences on self-reported offending, as well as indirect influences that is mediated by legal socialization. Accordingly, we estimated models for each of three types of self-reported offending that includes the predicted values for legitimacy and legal cynicism from the models in Table 4, and direct influences of rational choice and procedural justice variables. Results are shown in Table 5.

\section{Insert Table 5}

Results for total self-reported crimes appears in the first column in Table 5. Elements of each of the theoretical domains are significant predictors of offending over time. Again, we focus on the interactions of each predictor with time (exponentiated) to identify influences on patterns of offending over time. Both legitimacy and legal cynicism are significant predictors self-reported offending, but legitimacy only predicts at a relaxed threshold of $\mathrm{p}<.10$. Sanction risk (punishment risk) and both personal and social rewards of crime also predict self-reported offending. One of the two punishment cost factors - material costs also predicts self-reported offending.

For aggressive offending, the second column in Table 4 shows a similar pattern. Both legal socialization variables are significant predictors of trajectories of aggressive offending, but both are significant at the relaxed threshold of $p<.10$. Punishment risk and social rewards are both significant predictors, showing that a tension between risk and reward in aggressive offending. Personal rewards, or "thrills," is not significant in this model, indicating that perhaps the rewards of aggression derive from its functional benefits - especially status - rather than its visceral enjoyment. In this model, procedural justice is significant, but in a direction not predicted by theory. Fair and respectful treatment by judges predicts higher rates of aggressive offending. This might hint at the limits if not the downside of judicial philosophies that are oriented toward a therapeutic courtroom rather than a harsh procedural or sanctioning judicial process.

The results for income offending are similar to the results for total offending. Elements of risk (punishment risk), reward (social and personal rewards), and cost (material punishment costs) are significant predictors of selfreported income offending.

\section{DISCUSSION}

These results suggest that there are processes of legal socialization and rational choice that influence patterns of self-reported offending among serious 
juvenile offenders. Legal socialization includes two distinct dimensions that reflect different perceptual frameworks for how adolescents evaluate law and legal institutions. Each component directly affects criminal behavior over a two year period following a court appearance and sanction. We also observe direct effects of factors associated with rational choice theories. Both the perception of sanction risk and evaluations of experienced punishment compete with perceived and experienced rewards of crime to influence patterns of offending over time. These work both indirectly through legal socialization, especially through legitimacy, and directly on decisions to engage in or desist from crime.

Procedural justice also influences offending, but its affects are mediated by legitimacy. Evaluations of respondents' interaction quality with police and judges influences legitimacy over time, although it has no influence on legal cynicism. Although legal cynicism directly influences offending, the factors that seem to shape its trajectory over time lie outside this theoretical framework, perhaps in other developmental domains that are more influenced by personality and other individual-level variables than the social interactionist constructs in this theoretical framework.

The process of legal socialization influences their offending trajectories over a relatively short time period of two years. Perhaps the experience of sanctions activates these processes, but we find little sanction sensitivity to specific types of punishment costs. Instead, we observe that perceptions of law and legal actors, and evaluations of the sanctioning environment that they create, contribute to variation in offending patterns over time. Evaluations of the legitimacy of law and legal authorities grow slowly but steadily over time, contributing to the decline in offending in the initial waves and to sustain lower crime rates in later waves.

These findings are consistent with that of studies of general population samples of adults (Sunshine and Tyler, 2003; Tyler, 1990; Tyler and Huo, 2002), and community samples of adolescents (Fagan and Tyler, 2006). Since most crime is committed by thye types of adolescents in this study, the findings suggest the importance of focusing on socialization to better understand when and how values are acquired, even among active juvenile offenders. Theories of legitimacy and legitimation become more important if the values which are at their focus play an important role in the legal system. One way that they could do so is by shaping law related behavior, since social order depends upon widespread compliance with the law. This study supports general population studies of both juveniles and adults in suggesting that they do. This extension is important, since the vast majority of crimes are committed by adolescents. Based upon the findings of this study it can be argued that beginning in adolescence legitimacy is an important value shaping law related behavior.

This study also helps us to understand how legitimation occurs. Prior studies suggest that people's views about the legitimacy of authority are primarily linked to their evaluations of the procedures by which the police and courts operate. This study supports this procedural justice argument among adolescents. Like adults, adolescent views about the legitimacy of authority are influenced by procedural justice judgments about their own and others experiences with the 
police. The finding that procedural justice issues matter to adolescence is consistent with the results of several other recent studies. Fondacaro, Dunkle, and Pathak (1998) found that the procedural justice by which parents resolve family disputes influences rule following in both family and community contexts. And, Otto and Dalbert (2005) found that whether incarcerated adolescents felt guilt over their crimes was shaped by whether they viewed their trial as fairly conducted.

Of course, it is recognized that the process of socialization involves the development of a broader range of values, including attitudes toward democracy, views about other social groups, and tolerance of diversity. Further, it leads to many forms of potentially important behavior. Engagement in communities and in the political process is important, and is linked to values learned in childhood (Flanagan and Sherrod, 1998). Hence it is important to emphasize that this study concerns only one aspect of the general process of value socialization, as well as only speaking to one form of socially relevant behavior. 


\section{REFERENCES}

Anderson, E. (1999). Code of the Street. New York: Norton.

Apospori, A., Alpert, G.P. \& Paternoster, R. 1992. The effect of involvement with the criminal justice system: A neglected dimension of the relationship between experience and perceptions. Justice Quarterly 9(3): 379-392.

Blasi, A. 1980. Bridging moral cognition and moral action. Psychological Bulletin, 88, 1-45.

Casper, J., Tyler, T., and Fisher, B. (1988). Procedural justice in felony cases. Law and Society Review, 22(3) 483-507.

Chassin, L., Rogosch, F., and Barrera, M. (1991). Substance use and symptomatology among adolescent children of alcoholics. Journal of Abnormal Psychology, 100(4), 449-463.

Clarke, Ronald V. and Derek B. Cornish. 1985. Modeling offenders' decisions: a framework for research and policy. In Michael Tonry and Norval Morris (Eds.). Crime and Justice, 4. Chicago, IL: University of Chicago Press.

Cohn, E.S., and White, S.O. 1990. Legal Socialization: A Study Of Norms And Rules. N.Y.: Springer-Verlag.

Decker, Scott H., Richard T. Wright, and Robert Logie. 1995. "Criminal expertise and offender decision making: An experimental study of the target selection process in residential burglary." Journal of Research in Crime and Delinquency 32(1): 39-53.

DeLucia, C., Belz, A., and Chassin, L. (2001). Do adolescent symptomatology and family environment vary over time with fluctuations in paternal alcohol impairment? Developmental Psychology, 37(2), 207-216.

Derogatis, L. \& Melisara, N. (1983). The Brief Symptom Inventory: An introductory report. Psychological Medicine, 13 (3), 595-605.

Easton, D. 1965. A Systems Analysis Of Political Life. Chicago: University of Chicago Press.

Easton, D., and Dennis, J. 1969. Children In The Political System. Chicago: University of Chicago Press.

Fagan, J., and D.L. Wilkinson, (1998a). Guns, Youth Violence and Social Identity." Youth Violence (M. Tonry and M.H. Moore, eds.). Crime and Justice: A Review of Research 24: 373-456. 
Fagan, J.A., and Wilkinson, D.L. (1998B). The Social Contexts and Developmental Functions of Adolescent Violence. P. 89-133 in Violence in American Schools, edited by Delbert S. Elliott, Beatrix A. Hamburg, and Kirk R.Williams. New York: Cambridge University Press, 1998.

Fagan, J.A. (1994). Do Criminal Sanctions Deter Drug Offenders? Pp. 188-214 in Drugs and Criminal Justice: Evaluating Public Policy Initiatives, edited by Doris MacKenzie and Craig Uchida. Newbury Park, CA: Sage Publications, 1994.

Gibbs, J.P. 1975. Crime, Punishment, and Deterrence. Amsterdam, The Netherlands: Elsevier Scientific Publishing Co.

Grasmick, H.G. and R.J. Bursik, Jr. 1990. "Conscience, significant others, and rational choice: Extending the deterrence model." Law and Society Review 24(3):837-861.

Greenberger, E. \& Bond, L. (1976). Technical manual for the Psychosocial Maturity Inventory. Unpublished manuscript, Program in Social Ecology, University of California, Irvine.

Greenberger, E., Josselson, R., Knerr, C., \& Knerr, B. (1974). The measurement and structure of psychosocial maturity. Journal of Youth and Adolescence, 4, $127-$ 143.

Greenstein, F. 1965. Children and politics. New Haven: Yale

Hoffman, M. 2000. Empathy and moral development. Cambridge: Cambridge University Press.

Huizinga, D., \& Jakob-Chien, C. (1999). The contemporaneous co-occurrence of serious and violent juvenile offending and other problem behaviors. In R. Loeber \& D. P. Farrington (Eds.), Serious And Violent Juvenile Offenders: Risk Factors And Successful Interventions (pp. 47-67). California: Sage Publications.

Hyman, H. 1959. Political Socialization. N.Y.: Free press.

Katz, J. 1988. Seductions of Crime. New York: Basic Books.

Kessler RC, McGonagle KA, Zhao S et al. 1994. Lifetime and 12-month prevalence of DSM-III-R psychiatric disorders in the United States. Results from the National Comorbidity Survey. Arch Gen Psychiatry 51(1):8-19.

Krislov, S., Boyum, K.O., Clark, J.N., Shaefer, R.C., and White, S.O. 1966. Compliance and the law. Beverly Hills: Sage. 
Laub, John H. and Robert J. Sampson. 2001. Understanding desistance from crime. In Michael Tonry (Ed.), Crime and Justice: A Review of Research, Volume 28. Chicago: University of Chicago Press.

Link, B.G., Monahan J., Stueve A., \& Cullen, FT (1999).: Real in their consequences: a sociological approach to understanding the association between psychotic symptoms and violence. American Sociological Review, 64:316-322

Link, Bruce G., Stueve A, \& Phelan J (1998). Psychotic symptoms and violent behaviors: probing the components of "threat/control-override" symptoms. Social Psychiatry and Psychiatric Epidemiology 33:S55-S60

Loeber, R., Farrington, D. P., Stouthamer-Loeber, M., \& Van Kammen, W. B. (1998). Multiple risk factors for multiproblem boys: Co-occurrence of delinquency, substance use, attention deficit, conduct problems, physical aggression, covert behavior, depressed mood, and shy/withdrawn behavior. In R. Jessor (Ed.), New perspectives on adolescent risk behavior (pp. 90-149). New York: Cambridge University Press.

McCullough, C.E., \& Searle, S.R. (2001). Generalized, Linear and Mixed Models. New York: Wiley.

Melton, G.B. 1985. The law as a behavioral instrument. Nebraska Symposium on Motivation (Vol. 33). Lincoln, NE: University of Nebraska Press.

Merelman, R.J. 1986. Revitalizing political socialization. J. Knutson (Ed.), Political Psychology.

Mussen, P., and Eisenberg-Berg. 1977. Roots of caring, sharing, and helping. San Francisco: Freeman.

Nagin, D. S. and Paternoster, R. (1993). Enduring individual differences and rational choice theories of crime. Law and Society Review, 27, 467-469.

Nagin, D.S. 1998. "Criminal deterrence research at the outset of the twenty-first century." In M. Tonry (ed.), Crime and Justice: A Review of Research. Vol. 23. Chicago: University of Chicago Press.

Nagin, D.S. 1998. "Criminal deterrence research at the outset of the twenty-first century." In M. Tonry (ed.), Crime and Justice: A Review of Research. Vol. 23. Chicago: University of Chicago Press.

Nagin, D.S., and G. Pogarsky. 2001. "Integrating celerity, impulsivity, and extralegal sanction threats into a model of general deterrence: theory and evidence." Criminology 39(4):404-430. 
Nagin, D.S., and R. Paternoster. 1993. "Enduring Individual Differences and Rational Choice Theories of Crime." Law and Society Review 27(3):467-496.

Niemi, R.G. 1973. Political Socialization, in J.N. Knutson (Ed.), Political Psychology. San Francisco: Jossey-Bass.

Paternoster, R. 1987. "The deterrent effect of the perceived certainty and severity of punishment: a review of the evidence and issues." Justice Quarterly 4(2):173217.

Piquero, A.R., and G. Rengert. 1999. "Studying Deterrence with Active Residential Burglars.” Justice Quarterly 16:451-471.

Parsons, T. 1967. Some reflections on the place of force in social process. In T. Parsons (Ed.), Sociological Theory And Modern Society. N.Y.: Free press.

Paternoster, R. 1987. "The deterrent effect of the perceived certainty and severity of punishment: a review of the evidence and issues." Justice Quarterly 4(2):173217.

Paternoster, R., Brame, R., Bachman, R., and Sherman, L.W. (1997). Do fair procedures matter? The effect of procedural justice on spouse assault. Law and Society Review, 31, 163-204.

Piquero, A. R. and Tibbetts, S G. (1996). Specifying the direct and indirect effects of low self-control and situational factors in offenders' decision making: toward a more complex model of rational offending. Justice Quarterly, 13, 481-510.

Piquero, A.R., and G. Rengert. 1999. "Studying Deterrence with Active Residential Burglars.” Justice Quarterly 16:451-471.

Piquero, A.R., and S. Tibbetts. 1996. "Specifying the Direct and Indirect Effects of Low Self-Control and Situational Factors in Offenders' Decision Making: Toward a More Complete Model of Rational Offending." Justice Quarterly 13(3):481-510.

Piquero, Alex R., Lynn Langton, and Zenta Gomez-Smith. 2004. "Discerning unfairness where others may not: Low self-control and unfair sanction perceptions." Criminology 42(3): 693-727.

Pogarsky, G. 2002. "Identifying Deterrable Offenders: Implications for Deterrence Research." Justice Quarterly, in press.

Pogarsky, G. 2002. "Identifying Deterrable Offenders: Implications for Deterrence Research." Justice Quarterly, 19L701-720. 
Raudenbush, S.W., \& Bryk, A.S. (2002). Hierarchical Linear Models: Applications and Data Analysis Methods ( $2^{\text {nd }}$ edition). Thousand Oaks, CA: Sage.

Sampson, R.J. and Bartusch, D.J. (1999). Legal cynicism and tolerance of deviance: the neighborhood context of racial differences. Law and Society Review, 32(4), 777-804.

Sherman, L.W. 1993. Defiance, deterrence and irrelevance: A theory of the criminal sanction. Journal of Research in Crime and Delinquency, 30, 445-73.

Singer, J.D. 1998. "Using SAS PROC MIXED to fit multilevel models, hierarchical models, and individual growth models." Journal of Educational and Behavioral Statistics, 24(4):323-355.

Singer, Judith D., and Willett, John B. (2004). Applied Longitudinal Data Analysis. New York: Oxford Unversity Press.

Smith, Douglas A. and Patrick R. Gartin. 1989. "Specifying Specific Deterrence: The Influence of Arrest on Future Criminal Activity." American Sociological Review 54:94-106.

Srole, L. (1956). Social integration and certain corollaries: An exploratory study. American Sociological Review, 21, 709-716.

Sunshine, Jason, and Tom R. Tyler. 2003. The role of procedural justice and legitimacy in shaping public support for policing. Law and Society Review 37:XXX-XXX.

Tapp, J.L., and Levine, F. 1977. Law, Justice, And The Individual In Society.

Tittle, C.R. 1980. Sanctions and Social Deviance. New York: Praeger.

Torney, J. 1967. The Development Of Political Attitudes In Children.

Tunnell, Ken. 1992. Choosing Crime: The Criminal Calculus of Property Offenders. Chicago: Nelson-Hall.

Tunnell, Ken. 1992. Choosing Crime: The Criminal Calculus of Property Offenders. Chicago: Nelson-Hall.

Tyler, T. (1997). Procedural fairness and compliance with the law. Swiss Journal of Economics and Statistics, 133 (2/2), 219-240.

Tyler, T.R. 1990. Why People Obey the Law. New Haven CT: Yale University Press. 
Tyler, T.R., and Huo, Y.J. 2002. Trust In The Law: Encouraging Public Cooperation With The Police And Courts. N.Y.: Russell-Sage Foundation

Williams, K., and R. Hawkins. 1986. "Perceptual Research on General Deterrence: A Critical Overview." Law and Society Review 20: 545-572.

Wilkinson, D.L., and Fagan, J. (2001). A Theory of Violent Events. Pp. 169-97 in The Process and Structure of Crime Advances in Criminological Theory, Volume 9, edited by Robert Meier and Leslie Kennedy. New Brunswick, NJ: Transaction Publishers (2001).

Wright, Richard T. and Scott H. Decker. 1994. Burglars on the Job: Streetlife and Residential Break-ins. Boston: Northeastern University Press.

Wright, Richard T. and Scott H. Decker. 1997. Armed Robbers in Action: Stickups and Street Culture. Boston: Northeastern Univ. Press.

Zimring, F.E. and G.J. Hawkins. 1973. Deterrence: The Legal Threat in Crime Control. Chicago: University of Chicago. 


\section{Figure 1. Rational Choice and Developmental Influences on Recidivism}

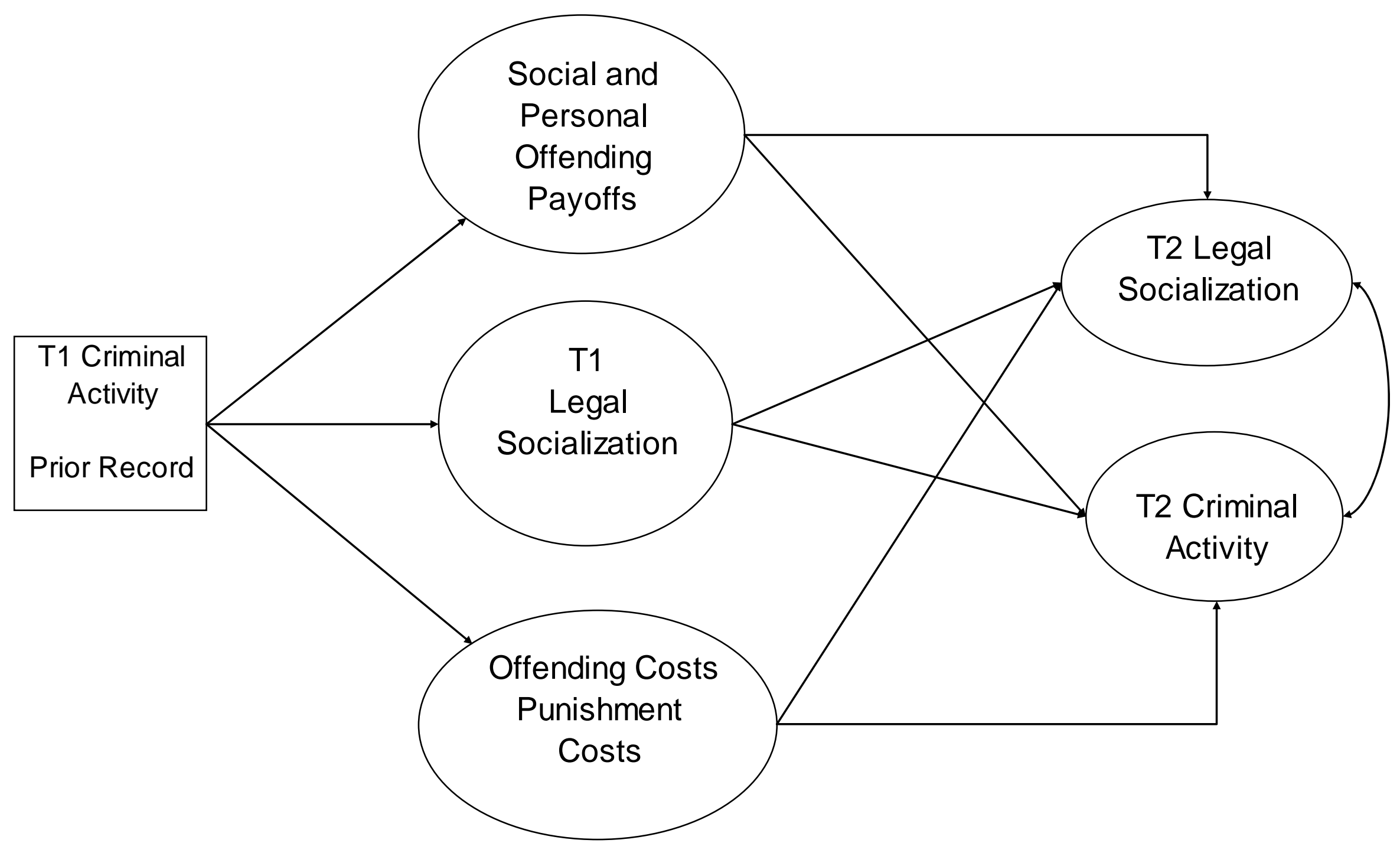


Figure 2. Legitimacy Index by Wave and Study Site

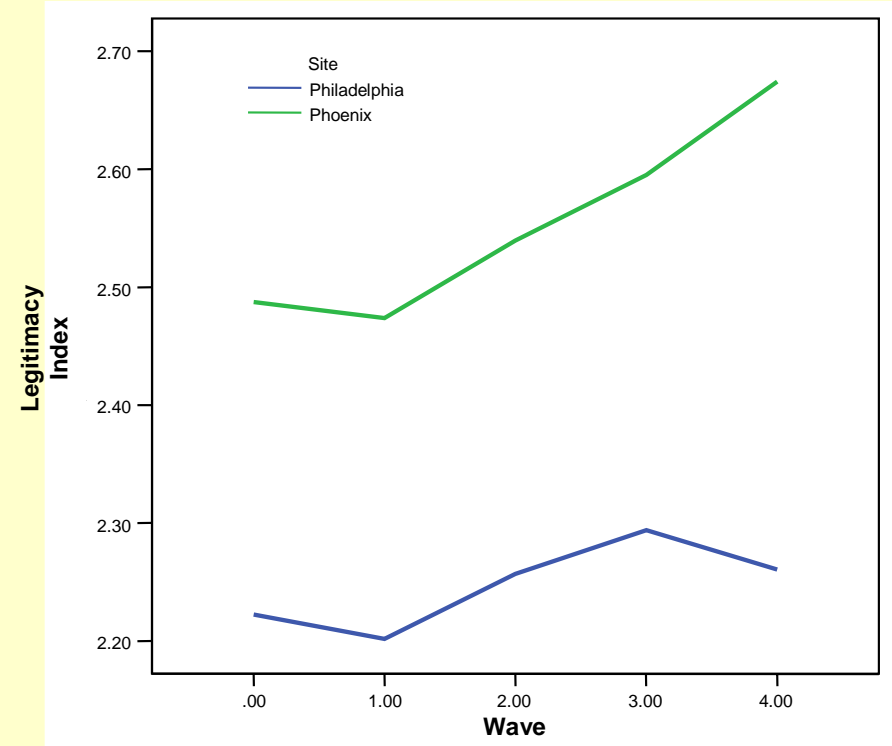

Figure 3. Legal Cynicism by Wave and Study Site

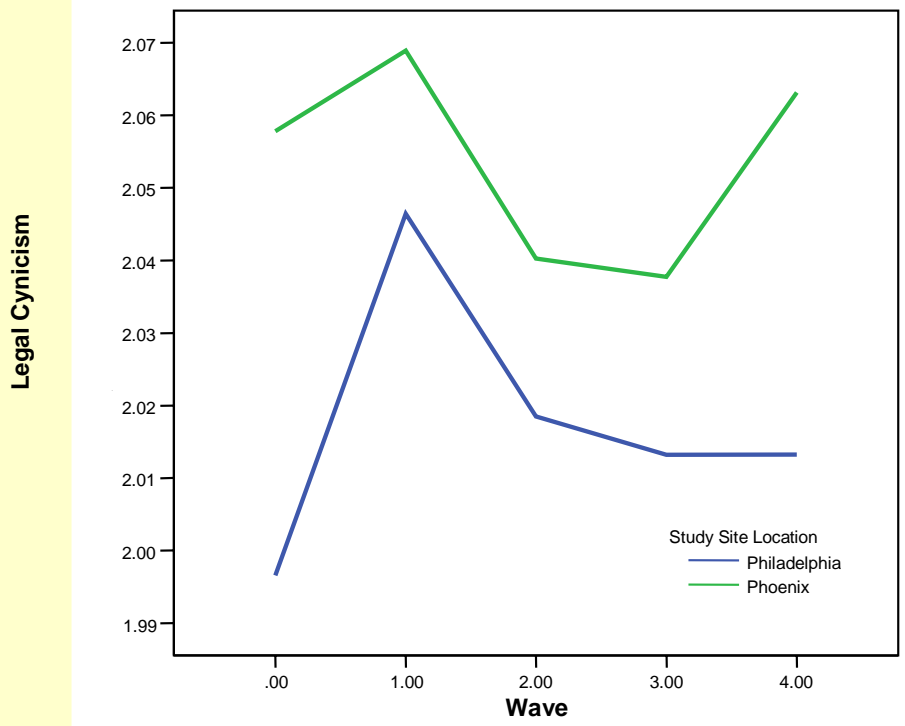




\section{Table 1. Respondent Social Characteristics and Legal Histories}

\begin{tabular}{lrr}
\hline $\begin{array}{l}\text { Variable } \\
\text { Site }\end{array}$ & $\boldsymbol{N}$ & $\%$ \\
$\quad$ Philadelphia & & \\
$\quad$ Phoenix & 700 & 51.7 \\
Gender & 654 & 48.3 \\
$\quad$ Male & & \\
$\quad$ Female & 1,170 & 86.4 \\
Race & 184 & 13.6 \\
$\quad$ White & & \\
$\quad$ Black & 274 & 20.2 \\
Hispanic & 562 & 41.5 \\
Other & 453 & 33.5 \\
Age at Intake & 65 & 4.8 \\
$\quad \leq 14$ & & \\
15 & 162 & 12.0 \\
16 & 255 & 18.8 \\
17 & 412 & 30.4 \\
$\geq 18$ & 413 & 30.5 \\
& 112 & 8.3
\end{tabular}

Family Structure

Both Parents

184

13.6

Single Mother

$458 \quad 33.8$

Mother/Stepfather

224

16.5

Single Father

Father/Stepmother

42

3.1

Other Adult Relatives

267

19.7

Other

117

8.7

Mothers' Education

$<$ HS Graduate

433

33.0

HS Graduate

357

27.2

Other

565

60.2

Juvenile Court Jurisdiction

1,111

82.1

Incarceration (baseline)

659

50.1

Prior Court Record (last 12 months)

Mean Std. Deviation

Petitions

1.69

1.24

Total Charges

4.19

2.92

Total Drug Charges 


\section{Table 2. Descriptive Statistics for Theoretical Variables at Baseline}

\begin{tabular}{|c|c|c|c|c|}
\hline Variable & Mean & S.D. & Minimum & Maximum \\
\hline Legal Cynicism & 2.1 & 0.6 & 1 & 4 \\
\hline Legitimacy & 2.3 & 0.6 & 1 & 4.7 \\
\hline Social Rewards & 5.8 & 1.5 & 3 & 11.6 \\
\hline Punishment Costs & 7.8 & 7.1 & 0 & 18 \\
\hline Material Costs & 5.9 & 5.4 & 0 & 13 \\
\hline Freedom Costs & 3.5 & 1.8 & 0 & 5 \\
\hline Personal Rewards & 2.3 & 2.5 & 0 & 10 \\
\hline Punishment Certainty - You & 5.2 & 3 & 0 & 10 \\
\hline Punishment Certainty - Others & 5.4 & 2.3 & 0 & 10 \\
\hline Social Costs of Punishment & 3 & 0.9 & 1 & 5 \\
\hline \multicolumn{5}{|l|}{ Procedural Justice } \\
\hline Police & 2.8 & 0.5 & 1 & 4.6 \\
\hline Judge & 3.1 & 0.6 & 1.0 & 4.9 \\
\hline BSI Global & 0.4 & 0.5 & 0.0 & 3.2 \\
\hline PSMI & 3.1 & 0.5 & 1.1 & 4 \\
\hline Drug Dependence & & & & \\
\hline
\end{tabular}


Table 3. Scale Properties at Baseline

\begin{tabular}{lcrrr}
\hline & Alpha & Chi-Squared & CFI & RMSEA \\
\cline { 2 - 5 } Sanction Likelihood-Others & 0.822 & 143.2 & 0.954 & 0.069 \\
Sanction Likelihood-You & 0.893 & 95.7 & 0.985 & 0.069 \\
Social Costs of Offending & 0.679 & 442 & 0.950 & 0.069 \\
Personal Rewards of Offending (Thrills) & 0.874 & 254.06 & 0.930 & \\
Social Rewards of Offending* & $.75-.82$ & na & $0.94-0.98$ & $.07-.08$ \\
Punishment Costs - Freedom & & & & \\
Punishment Costs - Material & & & & \\
& & & & \\
Procedural Justice - Police / You & 0.740 & 30.8 & 0.925 & 0.059 \\
Procedural Justice -Police / Others & 0.570 & 22.6 & 0.966 & 0.056 \\
Procedural Justice - Judge / You & 0.748 & 279.5 & 0.925 & 0.059 \\
Procedural Justice -Judge / Others & 0.652 & 90.6 & 0.939 & 0.078 \\
& & & & \\
Legitimacy & 0.786 & 297.7 & 0.921 & 0.07 \\
Legal Cynicism & 0.572 & 14.3 & 0.990 & 0.028 \\
& & & & \\
Self-Reported Offending: Total & 0.884 & 62.6 & 0.969 & 0.053 \\
Self-Reported Offending: Aggressive & 0.774 & 108.0 & 0.956 & 0.041 \\
Self-Reported Offending: Income & 0.798 & 122.2 & 0.954 & 0.056 \\
& & & & \\
Brief Symptom Inventory - GSI & 0.95 & & & \\
Psycho-Social Maturity Index & 0.89 & 1415.1 & 0.866 & 0.044 \\
Substance Dependence & & & &
\end{tabular}

* Social rewards is sum of three separate scales: fighting, stealing, robbery 
Table 4. Mixed Effects Regression of Theoretical Factors on Two Dimensions of Legal Socialization $^{\text {a }}$

\begin{tabular}{|c|c|c|c|c|c|c|}
\hline \multirow[b]{2}{*}{ Parameter } & \multicolumn{3}{|c|}{ Legitimacy } & \multicolumn{3}{|c|}{ Legal Cynicism } \\
\hline & Estimate & $t$ & $p(t)$ & Estimate & $t$ & $p(t)$ \\
\hline Wave & 0.010 & 1.23 & & -0.010 & -1.13 & \\
\hline Time2 & -1.009 & -6.80 & $\mathrm{a}$ & -0.274 & -1.95 & $\mathrm{~d}$ \\
\hline Legitimacy & & & & -0.094 & -5.03 & $\mathrm{a}$ \\
\hline Legal Cynicism & -0.095 & -5.54 & $\mathrm{a}$ & & & \\
\hline Punishment Risk & 0.113 & 11.10 & $\mathrm{a}$ & -0.053 & -4.90 & $\mathrm{a}$ \\
\hline Personal Rewards & -0.014 & -1.84 & $\mathrm{~d}$ & -0.022 & -2.89 & $\mathrm{~b}$ \\
\hline Social Rewards & -0.010 & -0.52 & & 0.161 & 8.53 & \\
\hline Social Costs & 0.007 & 1.46 & & -0.002 & -0.44 & \\
\hline Punishment Costs - Freedom & 0.007 & 0.97 & & 0.001 & 0.10 & \\
\hline Punishment Costs - Material & -0.009 & -3.18 & $\mathrm{a}$ & 0.001 & 0.26 & \\
\hline Procedural Justice - Police & 0.151 & 7.57 & $\mathrm{a}$ & -0.050 & -2.40 & $c$ \\
\hline Procedural Justice - Court & 0.184 & 9.53 & $\mathrm{a}$ & -0.009 & -0.43 & \\
\hline \multicolumn{7}{|l|}{ Interactions -- Time2 with: } \\
\hline Legitimacy & & & & 0.016 & 0.42 & \\
\hline Legal Cynicism & 0.035 & 1.12 & & & & \\
\hline Punishment Risk & -0.067 & -3.63 & a & -0.010 & -0.52 & \\
\hline Social Reward & -0.037 & -1.10 & & 0.001 & 0.02 & \\
\hline Social Cost & 0.055 & 3.13 & $\mathrm{~b}$ & -0.025 & -1.29 & \\
\hline Personal Reward & 0.002 & 0.16 & & 0.016 & 1.08 & \\
\hline Punishment Costs-Freedom & -0.018 & -1.47 & & 0.015 & 1.17 & \\
\hline Punishment Costs-Material & 0.014 & 3.29 & $\mathrm{a}$ & -0.004 & -0.90 & \\
\hline Procedural Justice - Police & 0.167 & 4.22 & $\mathrm{a}$ & 0.068 & 1.54 & \\
\hline Procedural Justice - Judge & 0.095 & 2.51 & $\mathrm{c}$ & -0.011 & -0.26 & \\
\hline$-2 \mathrm{LL}$ & \multicolumn{3}{|c|}{-7155.2} & \multicolumn{3}{|c|}{-7781.3} \\
\hline BIC & \multicolumn{3}{|c|}{-7180.8} & \multicolumn{3}{|c|}{-7806.9} \\
\hline
\end{tabular}

a. All estimates controlled for site, demographic characteristics, prior court record, incarceration, psychosocial maturity, mental health symptoms, and drug dependence symptoms.

Significance: $a: p<.001, b: p<.01, c: p<.05, d: p<.10$ 
Table 5. Mixed Effects Regression of Theoretical Factors on Three Types of Self-Reported Offending ${ }^{\mathrm{a}}$

\begin{tabular}{|c|c|c|c|c|c|c|c|c|c|}
\hline \multirow[b]{2}{*}{ Parameter } & \multicolumn{3}{|c|}{ SRO Variety } & \multicolumn{3}{|c|}{ Aggression } & \multicolumn{3}{|c|}{ Income } \\
\hline & Estimate & $t$ & $p(t)$ & Estimate & $t$ & $p(t)$ & Estimate & $t$ & $p(t)$ \\
\hline Wave & .015 & 8.40 & $\mathrm{a}$ & 0.008 & 4.22 & $\mathrm{a}$ & 0.020 & 9.08 & $\mathrm{a}$ \\
\hline Time2 & .264 & 6.16 & $\mathrm{a}$ & 0.210 & 4.71 & $\mathrm{a}$ & 0.304 & 5.89 & $\mathrm{a}$ \\
\hline Legitimacy (Predicted) & -.039 & 1.37 & & -0.036 & -3.71 & $\mathrm{a}$ & -0.040 & -3.55 & $\mathrm{a}$ \\
\hline Legal Cynicism (Predicted) & .020 & 8.40 & $\mathrm{a}$ & 0.019 & 2.14 & $\mathrm{c}$ & 0.017 & 1.73 & $\mathrm{~d}$ \\
\hline Punishment Risk & .003 & 1.25 & & 0.001 & 0.54 & & 0.001 & 0.48 & \\
\hline Personal Rewards & .000 & -4.08 & $\mathrm{a}$ & 0.002 & 1.35 & & 0.000 & 0.09 & \\
\hline Social Rewards & .007 & 2.33 & $\mathrm{c}$ & 0.004 & 1.01 & & 0.008 & 1.63 & \\
\hline Social Costs & -.001 & 1.25 & & -0.001 & -1.11 & & 0.000 & -0.05 & \\
\hline Punishment Costs - Freedom & -.001 & .14 & & -0.002 & -0.90 & & -0.001 & -0.57 & \\
\hline Punishment Costs - Material & .000 & 1.75 & $\mathrm{~d}$ & 0.001 & 2.19 & $\mathrm{c}$ & 0.000 & -0.47 & \\
\hline Procedural Justice - Police & .000 & -.66 & & 0.001 & 0.23 & & -0.002 & -0.35 & \\
\hline Procedural Justice - Court & .002 & -.79 & & -0.001 & -0.22 & & 0.004 & 0.63 & \\
\hline \multicolumn{10}{|l|}{ Interactions -- Time2 with: } \\
\hline Legitimacy (Predicted) & -0.031 & -1.86 & $\mathrm{~d}$ & -0.034 & -1.93 & $\mathrm{~d}$ & -0.034 & -1.68 & $\mathrm{~d}$ \\
\hline Legal Cynicism (Predicted) & 0.027 & 2.12 & $\mathrm{~b}$ & 0.025 & 1.92 & $\mathrm{~d}$ & 0.026 & 1.70 & $\mathrm{~d}$ \\
\hline Punishment Risk & -0.043 & -9.33 & $\mathrm{a}$ & -0.036 & -7.48 & $\mathrm{a}$ & -0.044 & -7.91 & $\mathrm{a}$ \\
\hline Social Reward & 0.025 & 3.00 & $\mathrm{~b}$ & 0.035 & 4.06 & $\mathrm{a}$ & 0.028 & 2.79 & $\mathrm{~b}$ \\
\hline Social Cost & 0.005 & 1.10 & & 0.006 & 1.34 & & 0.006 & 1.12 & \\
\hline Personal Reward & 0.009 & 2.72 & $\mathrm{~b}$ & 0.003 & 1.04 & & 0.010 & 2.52 & $\mathrm{c}$ \\
\hline Punishment Costs-Freedom & -0.003 & -0.95 & & -0.001 & -0.46 & & -0.004 & -1.26 & \\
\hline Punishment Costs-Material & 0.003 & 3.35 & $\mathrm{~b}$ & 0.001 & 1.17 & & 0.005 & 3.88 & $\mathrm{a}$ \\
\hline Procedural Justice - Police & -0.008 & -0.77 & & -0.008 & -0.69 & & -0.008 & -0.59 & \\
\hline Procedural Justice - Judge & 0.013 & 1.21 & & 0.022 & 2.04 & $\mathrm{c}$ & 0.014 & 1.08 & \\
\hline$-2 \mathrm{LL}$ & \multicolumn{3}{|c|}{-7554.6} & \multicolumn{3}{|c|}{-7106.1} & \multicolumn{3}{|c|}{-5620.5} \\
\hline $\mathrm{BIC}$ & \multicolumn{3}{|c|}{-7529.1} & \multicolumn{3}{|c|}{-7080.4} & \multicolumn{3}{|c|}{-5594.9} \\
\hline
\end{tabular}

a. All estimates controlled for site, demographic characteristics, prior court record, incarceration, psychosocial maturity, mental health symptoms, and drug dependence symptoms.

Significance: $a: p<.001, b: p<.01, c: p<.05$ 


\begin{tabular}{|c|c|c|c|c|c|c|c|c|c|c|c|c|c|}
\hline & $\begin{array}{c}\text { SRO- } \\
\text { General }\end{array}$ & $\begin{array}{c}\text { SRO - } \\
\text { Aggressive }\end{array}$ & $\begin{array}{c}\text { SRO - } \\
\text { Income }\end{array}$ & Legitimacy & $\begin{array}{c}\text { Legal } \\
\text { Cynicism }\end{array}$ & $\begin{array}{c}\text { Punishment } \\
\text { Risk }\end{array}$ & $\begin{array}{l}\text { Personal } \\
\text { Rewards }\end{array}$ & $\begin{array}{c}\text { Social } \\
\text { Rewards }\end{array}$ & $\begin{array}{c}\text { Social } \\
\text { Costs }\end{array}$ & $\begin{array}{c}\text { Punishment } \\
\text { Costs - } \\
\text { Freedom }\end{array}$ & $\begin{array}{c}\text { Punishment } \\
\text { Costs - } \\
\text { Material } \\
\end{array}$ & $\begin{array}{c}\text { Procedural } \\
\text { Justice - } \\
\text { Police } \\
\end{array}$ & $\begin{array}{c}\text { Procedural } \\
\text { Justice - } \\
\text { Judge }\end{array}$ \\
\hline \multirow{2}{*}{$\begin{array}{l}\text { SRO - } \\
\text { General }\end{array}$} & 1.000 & 0.917 & 0.945 & -0.177 & 0.192 & -0.167 & 0.303 & 0.315 & -0.024 & 0.135 & 0.141 & -0.157 & -0.062 \\
\hline & . & 0.000 & 0.000 & 0.000 & 0.000 & 0.000 & 0.000 & 0.000 & 0.081 & 0.000 & 0.000 & 0.000 & 0.000 \\
\hline \multirow{2}{*}{$\begin{array}{l}\text { SRO - } \\
\text { Aggressive }\end{array}$} & 0.917 & 1.000 & 0.792 & -0.172 & 0.187 & -0.154 & 0.298 & 0.309 & -0.027 & 0.126 & 0.137 & -0.151 & -0.067 \\
\hline & 0.000 & . & 0.000 & 0.000 & 0.000 & 0.000 & 0.000 & 0.000 & 0.054 & 0.000 & 0.000 & 0.000 & 0.000 \\
\hline \multirow{2}{*}{$\begin{array}{l}\text { SRO - } \\
\text { Income }\end{array}$} & 0.945 & 0.792 & 1.000 & -0.153 & 0.170 & -0.150 & 0.282 & 0.292 & -0.014 & 0.128 & 0.132 & -0.140 & -0.044 \\
\hline & 0.000 & 0.000 & . & 0.000 & 0.000 & 0.000 & 0.000 & 0.000 & 0.316 & 0.000 & 0.000 & 0.000 & 0.002 \\
\hline \multirow[t]{2}{*}{ Legitimacy } & -0.177 & -0.172 & -0.153 & 1.000 & -0.220 & 0.296 & -0.070 & -0.113 & 0.116 & -0.067 & -0.106 & 0.396 & 0.415 \\
\hline & 0.000 & 0.000 & 0.000 & . & 0.000 & 0.000 & 0.000 & 0.000 & 0.000 & 0.000 & 0.000 & 0.000 & 0.000 \\
\hline \multirow{2}{*}{$\begin{array}{l}\text { Legal } \\
\text { Cynicism }\end{array}$} & 0.192 & 0.187 & 0.170 & -0.220 & 1.000 & -0.160 & 0.245 & 0.335 & -0.053 & 0.064 & 0.049 & -0.140 & -0.110 \\
\hline & 0.000 & 0.000 & 0.000 & 0.000 & . & 0.000 & 0.000 & 0.000 & 0.000 & 0.000 & 0.000 & 0.000 & 0.000 \\
\hline \multirow{2}{*}{$\begin{array}{l}\text { Punishment } \\
\text { Risk }\end{array}$} & -0.167 & -0.154 & -0.150 & 0.296 & -0.160 & 1.000 & 0.008 & 0.000 & 0.092 & -0.024 & -0.057 & 0.177 & 0.143 \\
\hline & 0.000 & 0.000 & 0.000 & 0.000 & 0.000 & . & 0.547 & 0.998 & 0.000 & 0.080 & 0.000 & 0.000 & 0.000 \\
\hline \multirow{2}{*}{$\begin{array}{l}\text { Personal } \\
\text { Rewards }\end{array}$} & 0.303 & 0.298 & 0.282 & -0.070 & 0.245 & 0.008 & 1.000 & 0.835 & -0.019 & 0.062 & 0.006 & -0.055 & 0.000 \\
\hline & 0.000 & 0.000 & 0.000 & 0.000 & 0.000 & 0.547 & . & 0.000 & 0.163 & 0.000 & 0.646 & 0.000 & 0.991 \\
\hline \multirow{2}{*}{$\begin{array}{l}\text { Social } \\
\text { Rewards }\end{array}$} & 0.315 & 0.309 & 0.292 & -0.113 & 0.335 & 0.000 & 0.835 & 1.000 & -0.026 & 0.065 & 0.002 & -0.090 & -0.059 \\
\hline & 0.000 & 0.000 & 0.000 & 0.000 & 0.000 & 0.998 & 0.000 & . & 0.060 & 0.000 & 0.873 & 0.000 & 0.000 \\
\hline \multirow{2}{*}{$\begin{array}{l}\text { Social } \\
\text { Costs }\end{array}$} & -0.024 & -0.027 & -0.014 & 0.116 & -0.053 & 0.092 & -0.019 & -0.026 & 1.000 & 0.000 & -0.017 & 0.025 & 0.044 \\
\hline & 0.081 & 0.054 & 0.316 & 0.000 & 0.000 & 0.000 & 0.163 & 0.060 & . & 0.989 & 0.234 & 0.078 & 0.002 \\
\hline \multirow{2}{*}{$\begin{array}{l}\text { Freedom } \\
\text { Costs }\end{array}$} & 0.135 & 0.126 & 0.128 & -0.067 & 0.064 & -0.024 & 0.062 & 0.065 & 0.000 & 1.000 & 0.827 & -0.080 & -0.079 \\
\hline & 0.000 & 0.000 & 0.000 & 0.000 & 0.000 & 0.080 & 0.000 & 0.000 & 0.989 & . & 0.000 & 0.000 & 0.000 \\
\hline \multirow{2}{*}{$\begin{array}{l}\text { Material } \\
\text { Costs }\end{array}$} & 0.141 & 0.137 & 0.132 & -0.106 & 0.049 & -0.057 & 0.006 & 0.002 & -0.017 & 0.827 & 1.000 & -0.083 & -0.108 \\
\hline & 0.000 & 0.000 & 0.000 & 0.000 & 0.000 & 0.000 & 0.646 & 0.873 & 0.234 & 0.000 & . & 0.000 & 0.000 \\
\hline \multirow{2}{*}{$\begin{array}{l}\text { PJ - } \\
\text { Police }\end{array}$} & -0.157 & -0.151 & -0.140 & 0.396 & -0.140 & 0.177 & -0.055 & -0.090 & 0.025 & -0.080 & -0.083 & 1.000 & 0.541 \\
\hline & 0.000 & 0.000 & 0.000 & 0.000 & 0.000 & 0.000 & 0.000 & 0.000 & 0.078 & 0.000 & 0.000 & . & 0.000 \\
\hline \multirow{2}{*}{$\begin{array}{l}\text { PJ - } \\
\text { Judge }\end{array}$} & -0.062 & -0.067 & -0.044 & 0.415 & -0.110 & 0.143 & 0.000 & -0.059 & 0.044 & -0.079 & -0.108 & 0.541 & 1.000 \\
\hline & 0.000 & 0.000 & 0.002 & 0.000 & 0.000 & 0.000 & 0.991 & 0.000 & 0.002 & 0.000 & 0.000 & 0.000 & . \\
\hline
\end{tabular}


LEGAL SOCIALIZATION AND RATIONAL CHOICE 31

Appendix B. Pearson Correlations (Two-tailed) of Covariates with Predictors and Dependent Variables

\begin{tabular}{|c|c|c|c|c|c|c|c|c|c|}
\hline & $\begin{array}{c}\text { Incarceration } \\
\text { at Baseline }\end{array}$ & $\begin{array}{c}\text { Total Prior } \\
\text { Charges }\end{array}$ & Gender & Age & $\begin{array}{c}\text { African } \\
\text { American }\end{array}$ & Latino & PSMI & BSI - Global & $\begin{array}{c}\text { Drug } \\
\text { Dependence }\end{array}$ \\
\hline \multirow[t]{2}{*}{ SRO General } & .089 & -.080 & -.122 & 0.059 & -0.106 & 0.080 & -0.104 & 0.241 & 0.390 \\
\hline & .000 & .000 & .000 & 0.000 & 0.000 & 0.000 & 0.000 & 0.000 & 0.000 \\
\hline \multirow{2}{*}{ SRO - Aggressive } & .083 & -.063 & -.129 & 0.018 & -0.087 & 0.083 & -0.101 & 0.244 & 0.307 \\
\hline & .000 & .000 & .000 & 0.196 & 0.000 & 0.000 & 0.000 & 0.000 & 0.000 \\
\hline \multirow[t]{2}{*}{ SRO - Income } & .079 & -.074 & -.100 & 0.065 & -0.108 & 0.057 & -0.098 & 0.216 & 0.394 \\
\hline & .000 & .000 & .000 & 0.000 & 0.000 & 0.000 & 0.000 & 0.000 & 0.000 \\
\hline \multirow[t]{2}{*}{ Legitimacy } & -.106 & -.147 & .063 & -0.121 & -0.216 & 0.123 & 0.018 & -0.058 & -0.021 \\
\hline & .000 & .000 & .000 & 0.000 & 0.000 & 0.000 & 0.207 & 0.000 & 0.143 \\
\hline \multirow[t]{2}{*}{ Legal Cynicism } & .074 & -.018 & -.118 & 0.038 & -0.032 & 0.106 & -0.284 & 0.106 & 0.085 \\
\hline & .000 & .210 & .00 & 0.007 & 0.023 & 0.000 & 0.000 & 0.000 & 0.000 \\
\hline \multirow[t]{2}{*}{ Punishment Risk } & -.127 & -.115 & .151 & -0.130 & -0.122 & 0.041 & -0.049 & -0.014 & -0.005 \\
\hline & .000 & .000 & .000 & 0.000 & 0.000 & 0.003 & 0.000 & 0.306 & 0.701 \\
\hline \multirow[t]{2}{*}{ Personal Rewards } & -.016 & -.202 & -.079 & -0.024 & -0.245 & 0.133 & -0.208 & 0.144 & 0.202 \\
\hline & .253 & .000 & .000 & 0.088 & 0.000 & 0.000 & 0.000 & 0.000 & 0.000 \\
\hline \multirow[t]{2}{*}{ Social Rewards } & .003 & -.110 & -.111 & -0.015 & -0.143 & 0.093 & -0.301 & 0.187 & 0.189 \\
\hline & .809 & .000 & .000 & 0.282 & 0.000 & 0.000 & 0.000 & 0.000 & 0.000 \\
\hline \multirow[t]{2}{*}{ Social Costs } & -.033 & -.072 & .035 & 0.016 & -0.091 & 0.060 & -0.008 & 0.025 & 0.020 \\
\hline & .019 & .000 & .012 & 0.263 & 0.000 & 0.000 & 0.557 & 0.080 & 0.153 \\
\hline \multirow{2}{*}{$\begin{array}{l}\text { Punishment Costs } \\
\text { - Freedom }\end{array}$} & .221 & .020 & -.076 & 0.053 & 0.018 & -0.016 & -0.040 & 0.130 & 0.087 \\
\hline & .000 & .147 & .000 & 0.000 & 0.211 & 0.266 & 0.005 & 0.000 & 0.000 \\
\hline \multirow{2}{*}{$\begin{array}{l}\text { Punishment Costs } \\
\text { - Material }\end{array}$} & .348 & .091 & -.101 & 0.094 & 0.097 & -0.052 & -0.014 & 0.126 & 0.047 \\
\hline & .000 & .000 & .000 & 0.000 & 0.000 & 0.000 & 0.304 & 0.000 & 0.001 \\
\hline \multirow{2}{*}{$\begin{array}{l}\text { Procedural } \\
\text { Justice-Police }\end{array}$} & -.040 & -.070 & .044 & -0.095 & -0.032 & 0.023 & 0.034 & -0.134 & -0.065 \\
\hline & .005 & .000 & .002 & 0.000 & 0.021 & 0.109 & 0.017 & 0.000 & 0.000 \\
\hline \multirow{2}{*}{$\begin{array}{l}\text { Procedural Justice } \\
\text { - Judge }\end{array}$} & -.099 & -.120 & .049 & -0.075 & -0.132 & 0.088 & 0.031 & -0.119 & -0.011 \\
\hline & .000 & .000 & .001 & 0.000 & 0.000 & 0.000 & 0.027 & 0.000 & 0.443 \\
\hline
\end{tabular}

